\title{
BioéthiqueOnline
}

\section{The Supreme Court of Canada Ruling in Carter v. Canada: A New Era of End-of-Life Care for Canadians}

\section{Hadi Karsoho}

Volume 4, 2015

Reçu : 9 Feb 2015; publié : 13 Feb 2015

URI : https://id.erudit.org/iderudit/1035491ar

DOI : https://doi.org/10.7202/1035491ar

Aller au sommaire du numéro

Éditeur(s)

BioéthiqueOnline

ISSN

1923-2799 (numérique)

Découvrir la revue

Citer ce document

Karsoho, H. (2015). The Supreme Court of Canada Ruling in Carter v. Canada: A

New Era of End-of-Life Care for Canadians. BioéthiqueOnline, 4.

https://doi.org/10.7202/1035491ar 


\title{
The Supreme Court of Canada Ruling in Carter v. Canada: A New Era of End-of-Life Care for Canadians
}

\author{
LA TRIBUNE DE L'ÉDITEUR / EDITOR's SOAPBOX \\ Hadi Karsoho ${ }^{1,2}$ \\ Reçu/Received: 9 Feb 2015 \\ Publié/Published: 13 Feb 2015 \\ 2015 H Karsoho, Creative Commons Attribution 4.0 International License
}

Mots clés

aide médicale à mourir, Carter c. Canada, Cour suprême

du Canada, euthanasie, compétence constitutionnelle, législation

\section{Keywords}

physician-assisted dying, Carter v. Canada, Supreme Court of Canada, euthanasia, constitutional jurisdiction, legislation

\section{Affiliations des auteurs / Author Affiliations \\ ${ }^{1}$ Editor, BioéthiqueOnline \\ ${ }^{2}$ Department of Sociology, Department of Social Studies of Medicine, McGill University, Montreal, Canada}

\section{Correspondance / Correspondence}

Hadi Karsoho, hadi.karsoho@gmail.com

\section{Remerciements}

Cette Tribune a été écrite suivant la suggestion de Bryn Williams-Jones que je tiens à remercier chaleureusement pour son soutien. Je tiens également à remercier Elise Smith et Renaud Boulanger pour leurs commentaires et suggestions constructifs.

\section{Conflit d'intérêts}

Aucun déclaré

\section{Exonération}

Les opinions exprimées ici sont celles de l'auteur et ne reflètent pas nécessairement celles de la revue.

\section{Acknowledgements}

The idea for writing this Soapbox came from Bryn WilliamsJones and I gratefully acknowledge his suggestion and support. I would also like to thank Elise Smith and Renaud Boulanger for their constructive feedback.

\section{Conflicts of Interest \\ None to declare}

Disclaimer

The views expressed here are the author's and do not necessarily reflect those of the journal.

In a unanimous ruling released on February 6, 2015, the Supreme Court of Canada (SCC) found in Carter v. Canada (Attorney General) [1] that the federal Criminal Code [2] prohibitions on physicianassisted dying (PAD) to have infringed on Canadians' Charter rights to life, liberty, and security. With this historic judgment, Canada has become the second country in the world, after Colombia, to have allowed for PAD on constitutional grounds. ${ }^{1}$ Carter v. Canada had its origin with the death of a British Columbia woman, Kay Carter, at the Dignitas assisted suicide clinic in Switzerland. Slightly over a year later, Carter's daughter and son-in-law launched constitutional litigation along with the British Columbia Civil Liberties Association, a family medicine physician, and Gloria Taylor, a woman suffering from Amyotrophic Lateral Sclerosis. In 2012, the trial judge found for the claimants and ruled as unconstitutional the impugned prohibitions, a decision that was later overturned by the B.C. Court of Appeal. The SCC granted the claimants leave to appeal and heard oral arguments on October 15, 2014.

The SCC found sections $241(b)^{2}$ and $14^{3}$ of the Criminal Code to have infringed on Canadians' rights to life, liberty and security of the person guaranteed under section 7 of the Charter of the Rights and Freedoms [3]. The law infringes on the right to life insofar as it has the effect of forcing some

\footnotetext{
${ }^{1}$ The courts in Montana and New Mexico decriminalized physician-assisted suicide in 2009 and 2014 respectively; however, these decisions were based on state constitutions and their effects are thus limited to those jurisdictions.

${ }^{2}$ Section 241(b) prohibits anyone from aiding and abetting another person's suicide.

${ }^{3}$ Section 14 prohibits anyone from consenting to their own death.
} 
individuals to take their own lives prematurely for fear that they may be unable to do so at a later time when they will have become disabled or their suffering is too great. The law infringes on the right to liberty insofar as it deprives individuals of the right to make medical decisions concerning their own bodily integrity; and it infringes on the right to security because it forces some individuals to endure intolerable suffering. Further, the SCC found the law to be overly broad: the purpose of the law is to protect vulnerable individuals from being induced to commit suicide. The law, however, catches others outside of this group of protected persons - i.e., other non-vulnerable individuals who wish to hasten their own deaths. More importantly, the infringement is not saved by section 1 of the Charter - the Charter provision that allows the state to curtail constitutional rights in the interests of society because the Court agreed with the trial judge that evidence from Canada and abroad showed there to be less restrictive means to protect vulnerable individuals, other than an absolute prohibition.

Reading media reports published soon after the release of the decision, bioethicists might be forgiven for thinking that this case is concerned only with physician-assisted suicide. Many national and international media refer to assisted suicide in their headlines and bodies of texts when discussing the practice at the heart of this case [4-7]. But make no mistake: the SCC decriminalized both euthanasia and physician-assisted suicide, practices that many bioethicists have long recognized to be ethically related but which may be distinguished in practical terms. The American Medical Association's Code of Medical Ethics, for example, defines physician-assisted suicide (PAS) as "when a physician facilitates a patient's death by providing the necessary means and/or information to enable the patient to perform the life-ending act" [8]. Euthanasia is distinguished from PAS in that another person - a physician in places that have legalized euthanasia - administers the life-ending act. Specifically, the SCC decriminalized "physician-assisted death" or "physician-assisted dying" and it accepted the claimants' definition of this term as a "situation where a physician provides or administers medication that intentionally brings about the patient's death, at the request of the patient." [1]

The obfuscation in the media may be unintentional; contrary to popular understanding, the terms 'euthanasia' and 'physician-assisted suicide' are not self-explanatory. In the last couple of decades, these terms have evolved to acquire highly technical specificities. They are, in other words, legal and clinical (not to mention ethical) constructs, labels that can be understood only in terms of their legal and clinical enactment at a specific historical juncture. Even one of the SCC justices was initially confused as regards the use and implication of these terms. When I attended the hearing last October, Justice LeBel interrupted the counsel for the claimants early in the proceeding when he asked if "we are discussing strictly assisted suicide, we are not discussing euthanasia this morning?" [9] Further, the SCC may itself be partly to blame for the confusion. In its 85-page decision, the SCC shied away from using the term 'euthanasia'. The one time it used the term substantively was in the context of a discussion of the slippery slope argument: "Finally, it is argued that without an absolute prohibition on assisted dying, Canada will descend the slippery slope into euthanasia and condoned murder." [1] A careful reading of this paragraph revealed that the SCC had used the term 'euthanasia' much as a bioethicist would use the term 'involuntary euthanasia', that is, killing someone against their own wishes, or culpable homicide. So it ought to be clear for readers that Carter $v$. Canada has decriminalized both 'physician-assisted suicide' and 'voluntary active euthanasia', as they are conventionally understood in the bioethics literature.

In the aftermath of this decision, what does a Canadian PAD regime look like? Here, it is instructive to recall the distinction between decriminalization and legalization. The SCC has just decriminalized PAD. The only criteria for access to the practice that the SCC specified are: a) being a competent adult; b) having a clear consent; and c) having a diagnosis of a grievous and irremediable medical condition that causes suffering that is intolerable to the individual. The SCC has thus only set the 'floor' of the regime; the 'ceiling' is to be determined by the federal and provincial governments in terms of the legislation they will enact, should they choose to do so. One intervener exclaimed that the "judgment permits assisted suicide on the basis of psychological suffering." [10] But the SCC specified no such thing; it leaves the possibility for such criterion to be articulated by governments in their 
legislation. So far, Quebec is the only province that has passed a law on PAD, Bill 52: An Act respecting end-of-life care [11], set to take effect in December 2015. While Quebec's law will allow for patients with irremediable and unbearable psychological suffering to request medical aid-in-dying, it also stipulates that the patient must be at the end of his or her life.

The issue of inter-jurisdictional immunity was also addressed by the SCC. One of the questions the SCC was asked to consider - a question that was raised only at the SCC level after the passage of Quebec's Act respecting end-of-life care - was whether the Criminal Code prohibitions could not apply on the issue of PAD because they encroached on healthcare, a constitutionally protected area of provincial competence. The SCC answered this question in the negative and reaffirmed instead that health "is an area of concurrent jurisdiction, which suggests that aspects of physician-assisted dying must be the subject of valid legislation by both levels of government, depending on the circumstances and focus of the legislation." [1] This finding by the SCC means that the federal government could, in theory, modify the Criminal Code in such a way as to conflict with Quebec's Act, which would then certainly lead to another constitutional battle in the court. I hope the federal government avoids the adversarial route and chooses instead to work with the provincial governments in creating a new legislation, especially to ensure uniformity of the regimes across the country.

The ball is now clearly in the federal government's court. The federal justice minister had promised that the government would "study the decision and ensure all perspectives on this difficult issue are heard." [12] Quebec could provide a model with the public and expert consultation process it conducted leading up to and during the creation of Bill 52. However, that process took five years and the federal government does not have the luxury of time. It therefore ought to work with invested stakeholders such as the Canadian Medical Association and other healthcare professionals' associations in crafting legislation. While individual bioethicists have been active participants in the debate, the Canadian Bioethics Society has been strangely silent. Now that the conversation has shifted to the substance of subsequent legislation, the Canadian Bioethics Society ought to look into ways in which it can contribute meaningfully to this process. I have no doubt that the SCC ruling in Carter v. Canada will have ripple effects beyond the borders of this country, much as the legalization of PAD in other jurisdictions has been an important historical condition of possibility for this case.

\section{List of References}

1. Carter v. Canada (Attorney General) 2015 SCC 5.

2. Criminal Code R.S.C., 1985, c. C-46

3. Canadian Charter of Rights and Freedoms, Constitution Act, 1982

4. Austen, Ian. (2015, February 6). Canada Court Strikes Down Ban on Aiding Patient Suicide, The New York Times.

5. Clark, Campbell. (2015, February 7). Timing of assisted suicide law could determine its contents, The Globe and Mail, p. A10.

6. Gallagher, James. (2015, February 6). Canada to allow doctor-assisted suicide. BBC News.

7. MacLeod, Ian. (2015, February 6 ). Supreme Court of Canada strikes down ban on doctorassisted suicide, National Post.

8. American Medical Association. (1996). Opinion 2.211 - Physician-Assisted Suicide.

9. StenoTran. (2014). Court transcript of the hearing of Carter v. Canada (Attorney General) 2015 SCC 5 on 10/15/2014.

10. Council of Canadians with Disabilities. (2015). Commentary on SCC Assisted Suicide Judgment in Carter v. Canada - Key Concerns.

11. Bill $n^{\circ} 52$ : An Act respecting end-of-life care, Assembléé nationale de Québec

12. MacKay, Peter. (2015, February 6). Statement by the Minister of Justice Regarding the Supreme Court of Canada Ruling in Carter et al. v. Attorney General of Canada. Government of Canada. 